\title{
Use of Smoking to Add Value to the Salmoned Trout
}

\author{
Eduardo Oliveira Salán ${ }^{1 *}$, Juliana Antunes Galvão ${ }^{1}$ and Marília Oetterer ${ }^{1}$ \\ ${ }^{I}$ São Paulo University; USP/ESALQ; Department of Agroindustry, Foods and Nutrition; ESALQ/USP; P.O. Box 9; \\ dusalan@esalq.usp.br; 13418-900; Piracicaba-SP - Brasil
}

\begin{abstract}
The objective of this study was to make a comparison between the characteristics of salmoned trout ( $\underline{\text { Salmo truta) }})$ and salmon (Salmo salar) in terms of coloration (CIE $\left.L^{*} a^{*} b^{*}\right)$, proximate composition, $p H$ and sensory attributes of fresh and smoked fillets in order to obtain a possible alternative for the substitution of imported salmon for Brazilian salmoned trout as a commercial equivalent for retail sales. Results showed that no statistical difference was found for most of the sensory attributes analyzed and for $\mathrm{pH}$. Although the coloration of the fillets presented a statistical difference, the trout presented a more intense coloration than the salmon, proving to be, therefore, convenient to agroindustry.
\end{abstract}

Key words: Fish conservation, Salmoned trout, Salmo salar, agroindustry

\section{INTRODUCTION}

The importance of fish is based on its contents of high-biological-value proteins, high digestibility, vitamins, especially $\mathrm{A}$ and $\mathrm{D}$, and on the quality of its lipid fraction, rich in unsaturated fatty acids and low cholesterol contents (Sanches, 1989). The typical reddish coloration of the Atlantic Salmon meat is mainly due to presence of astaxantine $(3,3$ '-dihydroxy $\quad-\beta, \beta$-carotene-4,4'-diene $), \quad$ and canthaxanthine $(\beta, \beta$-carotene-4,4'-diene $)$, which are carotenoids that are commonly used in the muscle pigmentation of salmons (Bjerkeng, 2000). For the fishing industry to be sustainably developed, the resources have to be as widely used as possible and not only traded as captured. Processing will certainly provide a higher production, less wasting, and, as smoking does not require specialized labor, a low production cost (Andrade and Oliveira, 2000).

Smoking process is one of the oldest conservation methods, especially in the fishing industry, and works by the action of chemical products in the meat, especially phenols and aldehydes, which prevent lipid oxidation and, together with organic acids, are the main preventers of microbial development. Only $2 \%$ of the world production is used with this objective (Burt, 1988; Ferreira, 1987; Nunes, 1999). In agroindustry, smoking is not only a conservation method, but also a flavor-, aroma- and coloration-improving method, which are attributes seeked by consumers (Ferreira, 1987). The shelf life of smoked fish products depends on the process adopted. If hot smoked, depending on the kind of packing and storage temperature, an average shelf life of 7 days is achieved. The quality indicators of smoked fish are shiny, no-salt surface, uniform and golden coloration and consistent texture. The degree of changes in texture will depend on some variables, especially the dehydration level occurred during the smoking process and the salt (Nunes, 1999).

\footnotetext{
* Author for correspondence
} 
Cold smoked Atlantic salmon is a gastronomic specialty in several countries, especially the United States, where fish smoking has long been a tradition (Sigurgisladottir et al., 2001). The process includes salting and drying and the products typically have about 2 to $3.9 \%$ salt (Huang et al., 2002). Salt may be added by injection, dry salting or brining, being the two last processes most widely adopted by industry (Mørkøre et al., 2001; Espe et al., 2001). Smoking can be performed by hot, cold and electrostatic methods (Nunes, 1999). Both hot and cold smoking are low cost processes, whose only difference is the temperature in the smoking chamber, which is over $55^{\circ} \mathrm{C}$ in cold smoking (Oetterer, 1999).

Adding value to acquacultural products has been a frequent concern for fish producers which was started by trout producers, who smoke trouts as an essential practice to sell these products to restaurants, where the European tradition of using smoked salmon as a fine entrée is followed (Oetterer, 1994).

The objective of this work was to use smoking technique as a way of adding value to salmoned trout in order to find a possible alternative to the replacement of salmon by trout as a commercial alternative to retail sales, presenting it to consumers as a differentiated product and justifying it by the high prices of imported fished smoked salmon and by the fact that trout production is one of the most organized and developed sectors of national acquaculture.

\section{MATERIALS AND METHODS}

Frozen salmon (Salmo salar) fillets $(700 \mathrm{~g})$ and salmoned trouts (Salmo truta) (400g each) were purchased in Piracicaba, SP, Brazil, and stored at $18^{\circ} \mathrm{C}$ in the stores (frozen at $-25^{\circ} \mathrm{C}$ in industry). The fishes were hot smoked in a brick smoker as described by Oetterer (1999).

\section{Smoking Process}

The fillets were defrosted for $24 \mathrm{~h}$ at $1 \pm 1^{\circ} \mathrm{C}$, and then submitted to the finishing process. After that, they were immersed in a $\mathrm{NaCl} 25 \%(\mathrm{w} / \mathrm{v})$ solution at a ratio of $1: 2$, fish and brine, respectively, for a period of 30 minutes. After brining, the fishes were rinsed in running water in order to remove salt, drained and then placed on elevated racks and put into the drier with forced air circulation at $45^{\circ} \mathrm{C}$ for 30 minutes. At the end of the pre-drying operation, the fillets were kept on the same racks and put in the brick smoker.

Smoking of the fishes was carried out for $6 \mathrm{~h}$. The temperature inside the fillets was approximately $60^{\circ} \mathrm{C}$; the maximum temperature in the smoking chamber was $100^{\circ} \mathrm{C}$. The smoke was produced by the burning of sawdust from several kinds of wood and the heat source used was vegetal coal purchased from local shops. After smoking, the product was packed in polyethylene trays and covered by PVC films with a sealing machine and conserved at $1 \pm 1^{\circ} \mathrm{C}$ for 7 days.

\section{Physical-chemical analyses}

Physical-chemical analyses of both the fresh fillets and the smoked fillets were carried out in triplicates, in accordance with the AOAC, 1995. Moisture was determined by a FANEM oven at $105^{\circ} \mathrm{C} \pm 1^{\circ} \mathrm{C}$ with the plates being weighed until constant weight was reached. The ash content was determined by the incineration of the organic matter in flame, with posterior calcination in a muffle at $550^{\circ} \mathrm{C}$.

The lipid content was determined by extraction with hexane, by Soxhlet's method and $\mathrm{pH}$ was determined through a triturated sample at the ratio of 1:1 (distilled water:fillet) and subsequent reading in a Digimed digital potentiometer. The protein content was obtained through the determination of total nitrogen by Kjeldahl's method, and protein conversion, multiplying the obtained value by factor 6.25 (AOAC, 1995). The color values determination was performed by a Minolta CR300 colorimeter (Osaka, Japan), which obtained the reading of parameters: $L^{*}$ (luminosity), $a^{*}$ (intensity of color red) and $b^{*}$ (intensity of color yellow) (Hunt, 1977).

\section{Sensory analysis}

The sensory analysis was carried out in accordance with Post et al. (1991). A hedonic 9-point scale was used and the following attributes were used: aroma, color, flavor and appearance. Sixteen panelists were recruited who, despite of being untrained, were habitual smoked fish eaters and represented possible consumers of the product. The samples were presented in coded containers covered in PVC film

\section{Statistical Analysis}

The results were submitted to variance analysis through the SANEST program (Zonta et al., 1986). 
The averages were compared by Tukey's test, adopting the significance level of $5 \%$.

\section{RESULTS AND DISCUSSION}

The $\mathrm{pH}$ values found for fresh and smoked trout were 6.26 and 6.45 , respectively. The average values found for fresh and smoked salmon were 6.23 and 6.38, respectively. The Industrial and Sanitary Inspection Regulations for Animal Products RIISPOA (BRASIL, 2001) sets 6.5 as the maximum $\mathrm{pH}$ value for the internal part of fresh fish and the values found in this study were within the established limits.

In studies carried out by Hultmann et al. (2003), a $\mathrm{pH}$ of 6.4 was found for fresh trout fillets, which was similar to the present results. Bugueño et al. (2003) analyzed the physical-chemical alterations of salmon fillets stored under vacuum and modified atmosphere and obtained the initial values of 6.16 for the smoked fillets. GonzalezFandos et al. (2004) studied the quality of trout fillets and obtained the nearly neutral initial $\mathrm{pH}$ values (6.46), which were slightly above the ones found in this research.

Table 1 shows the values of $L^{*}, a^{*}$ and $b^{*}$ for the smoked trout and salmon. There was a significant difference between the two species for all the observed parameters. Although the fresh salmon presented a stronger orangish hue when compared to the trout, after the smoking the situation was inversed, trout presented a more intense coloration when compared to the salmon. Previous studies with smoked salmon showed that the coloration was directly related to pigments received in their diet (Sheehan et al., 1998), with the lipid content in the fish (Rora et al., 1998) and the parameters applied during smoking (Cardinal et al., 2001). Evaluation and correlating the sensory characteristics of smoked salmon purchased in European markets with the physical-chemical and microbiological parameters, Cardinal et al. (2004), found values between 45.4 to $61.8,13.4$ to 34.2 , and 16.9 to 33.7 , respectively for parameters $\mathrm{L}^{*}, \mathrm{a}^{*}$ and $b^{*}$. These results were similar to the ones found in this work.

$\underline{\left.\text { Table } 1 \text { - Coloration ( } \mathrm{L}^{*}, \mathrm{a}^{*}, \mathrm{~b}^{*}\right) \text { of smoked trout and salmon fillets*. }}$

\begin{tabular}{c|c|c}
\hline Parameter** & Smoked salmoned trout & Smoked salmon \\
\hline $\mathrm{L}^{*}$ & $69.7 \pm 2.72 \mathrm{a}$ & $47.3 \pm 2.58 \mathrm{~b}$ \\
$\mathrm{a}^{*}$ & $26.7 \pm 1.36 \mathrm{a}$ & $11.5 \pm 0.44 \mathrm{~b}$ \\
$\mathrm{~b}^{*}$ & $30.2 \pm 3.16 \mathrm{a}$ & $18.8 \pm 2.69 \mathrm{~b}$ \\
\hline
\end{tabular}

(*) average of 3 repetitions

$(* *)$ averages followed by distinct letters differ at the $5 \%$ significance level

Table 2 - Humidity, protein, lipids and ash for fresh trout and salmon (averages*)

\begin{tabular}{c|c|c}
\hline Variables $* *(\mathbf{g} / \mathbf{1 0 0 g})$ & \multicolumn{3}{c}{ Treatments } \\
\cline { 2 - 3 } & \multicolumn{3}{|c}{ Trout } & Salmon \\
\hline Moisture & $69.31 \pm 0.77 \mathrm{~A}$ & $68.01 \pm 0.26 \mathrm{~A}$ \\
Proteins & $18.12 \pm 0.37 \mathrm{~A}$ & $17.48 \pm 0.27 \mathrm{~B}$ \\
Lipids & $10.43 \pm 0.11 \mathrm{~B}$ & $11.48 \pm 0.26 \mathrm{~A}$ \\
Ash & $0.88 \pm 0.19 \mathrm{~B}$ & $1.08 \pm 0.09 \mathrm{~A}$ \\
\hline
\end{tabular}

(*) average of 3 repetitions

(**) averages followed by distinct letters differ at the $5 \%$ significance level

Studies with smoked salmon had a significant reduction in the color parameters $\left(\mathrm{L}^{*}, \mathrm{a}^{*}\right.$ and $\left.\mathrm{b}^{*}\right)$ when compared to fresh fillets. The values for smoked salmon were 41.0, 9.5 and 8.4, for $\mathrm{L}^{*}$, a and $b^{*}$, respectively, which were slightly lower than the ones found in the present work for the same species (Rora et al., 1998).
In studies on the stability of astaxantine and canthaxanthine in fresh and smoked salmon during frozen-storage, the values found for $\mathrm{L}^{*}, \mathrm{a}^{*}$ and $\mathrm{b}^{*}$ at the beginning of the storage period were $36.3,6.73$ e 8.97 , respectively for smoked fillets of salmon fed with astaxantine, which were lower than the ones found in this study (Sheehan et al., 1998). 
Table 2 presents the moisture, protein, lipids and ash values for the fresh trout and salmon fillets, which showed that a significant $5 \%$ difference was not achieved only for humidity, with 68.01 and 69.31 for salmon and trout, respectively.

Lipids and ash values were significantly higher in salmon than in salmoned trout, whereas the protein levels were significantly higher in trouts than in salmon; These results are in accordance with Frank (1992).

In studies with salt diffusion in pre-rigor salmon fillets, for smoking, Rora et al. (2003) obtained the values of $63.5,19.01$ and $14.1 \%$ for moisture, protein and lipids, respectively, which were close to the ones found in the present study. In studies with salmon, Gonzalez-Fandos et al. (2004) obtained values of $6.55 \mathrm{~g} / 100 \mathrm{~g}$ for the lipid fraction, and $16.04 \mathrm{~g} / 100 \mathrm{~g}$ for the protein fraction. These values were lower than the ones found in this work.

Results expressed in Table 3 showed that the values of moisture for smoked trout were significantly higher than in the salmon submitted to the same treatment. For protein fraction, no significant difference was found for the treatments, and the values.

Table 3 - Moisture, protein, lipids and ash for trout and smoked salmon (averages*)

\begin{tabular}{l|cc}
\hline \multirow{2}{*}{ Variables* $(\mathbf{g} / \mathbf{1 0 0 g})$} & Trout & Treatments \\
\cline { 2 - 3 } & $64,83 \pm 0,31 \mathrm{~A}$ & $63,65 \pm 0,12 \mathrm{~B}$ \\
Moisture & $22,08 \pm 1,33 \mathrm{~A}$ & $20,62 \pm 2,20 \mathrm{~A}$ \\
Proteins & $10,21 \pm 0,04 \mathrm{~B}$ & $12,11 \pm 0,25 \mathrm{~A}$ \\
Lipids & $1,83 \pm 0,03 \mathrm{~B}$ & $2,45 \pm 0,23 \mathrm{~A}$ \\
Ash &
\end{tabular}

$(*)$ average of 3 repetitions

$(* *)$ averages followed by distinct letters differ at the $5 \%$ significance level

Smoked and fresh trout presented significantly lower values than that of the salmon for ash (Tables 2 and 3), which presented initially lower ash content for this fish. The studied fish species presented greater ash content for the smoked product than for the fresh product; this was due to loss of humidity during the smoking process, as well as were to the salt incorporated in the brining process in the ash fraction. Rasmussen et al. (2001) in a study with salmoned trout, found values of 72 and $19.4 \%$ of moisture and protein for the fresh matter, which were in accordance with the contents found in this (69.31 and $18.12 \%$, respectively). Leroi et al. (1998) found $57 \%$ of moisture, $16 \%$ of lipids, $4.6 \%$ of ash in coldsmoked salmon. It was observed that when cold- smoking was the adopted process, lipid and ash contents were higher.

As the comparison of the results of tables 2 and 3 showed in smoking, exudation cause the loss of lipids and moisture with a consequent relative increase in the protein fraction. This was also observed for the smoked trouts, which presented an estimated $20 \%$ increase of protein when compared to fresh trout. Cardinal et al. (2004) evaluated and correlated the sensory characteristics of smoked salmon obtained in European markets to physical-chemical and microbiological parameters and achieved values of moisture $(62.9 \mathrm{~g} / 100 \mathrm{~g})$ and lipids $(10.4 \mathrm{~g} / 100 \mathrm{~g})$ which were very close to the ones found in this work.

Table 4 - Average values $(*)$ of variables aroma, flavor, color and general for smoked trout e salmon.

\begin{tabular}{c|c|c|c|c}
\multirow{2}{*}{ Treat. } & \multicolumn{5}{|c}{ Variables $(* *)$} \\
\cline { 2 - 5 } & Aroma & Flavor & Color & General \\
\hline Trout & $5.31 \mathrm{~b}$ & $6.50 \mathrm{a}$ & $7.81 \mathrm{a}$ & $6.75 \mathrm{a}$ \\
Salmon & $8.00 \mathrm{a}$ & $7.37 \mathrm{a}$ & $6.87 \mathrm{a}$ & $6.69 \mathrm{a}$ \\
\hline
\end{tabular}

(*) average of 16 panelists

$(* *)$ averages followed by distinct letters differ at the $5 \%$ significance level 
The quality parameters thought to be applicable to fish quality evaluation usually include flavor, texture, and global appearance (Borresen, 1992). Sylvia et al. (1995) suggested that the salmon texture and flavor were the most important characteristics in consumers' preference for this fish. The results of Table 4 showed the only aspect panelists considered different between smoked salmon and trout was the aroma, with a lower grade for aroma, which, in fact, mean a more delicate aroma. No other significant difference was observed in the other attributes, and the trout was graded as 7.81 for the color attribute and the salmon 6.87 with no statistical significance.

\section{CONCLUSIONS}

It was concluded that the substitution of imported salmon by the Brazilian salmoned trout could be definitely proposed, once there were no significant sensory characteristics among the attributes analyzed and the color, which in fact determined consumers' choice, presented higher values for smoked trout than for salmon. The nutritional values of the species showed that both were excellent foods with high protein values, which was $22 \%$ in smoked salmoned trout.

\section{RESUMO}

O objetivo deste estudo foi comparar as características inerentes à truta salmonada (Salmo truta) e ao salmão (Salmo salar), no que se refere à coloração (CIE L $\left.{ }^{*}{ }^{*} b^{*}\right)$, composição centesimal, $\mathrm{pH}$ e atributos sensoriais, de filés in natura e defumados, visando uma possível alternativa para substituição do salmão importado pela truta salmonada brasileira, em termos de equivalência comercial para venda no varejo. Os resultados encontrados, mostraram que não ocorreu diferença estatística para a maioria dos atributos sensorias analisados e para o pH. Já a coloração dos filés apresentou diferença estatística indicando porém, uma coloração mais intensa para a truta em relação ao salmão, sendo, portanto, conveniente à agroindústria.

\section{REFERENCES}

Andrade, E. G. and Oliveira, P. R. (2000), A composição centesimal de quatro espécies de peixes de água doce, submetidas a um processo de defumação. In: Congresso Brasileiro de Ciência e Tecnologia de Alimentos, 12., Fortaleza. Resumos... Fortaleza.

Association of Official Agriculture Chemists (1995), Official methods of analysis. 16. ed. Washington: AOAC.

Bjerkeng, B. (2000), Carotenoid pigmentation of salmonids - recent progress. In: Cruz-Suarez, L. E.; Ricque-Marie, D.; Tapia-Salazar, M.; Olvera-Novoa, M. A. and Civera-Cerecedo, R. (Eds.). Avances en Nutricion Acuicola. Univesidad Autonoma de Nuevo Leon: Nuevo Leon. pp. 71-89.

Borresen, T. (1992), Quality aspects of wild and reared fish. In: Huss, H. H.; Jakobsen, M. and Liston, J. (Eds.). Quality Assurance in the Fish Industry. Amsterdam: Elsevier. pp. 1-17.

Brasil. Ministério da Agricultura, Pecuária e Abastecimento. Regulamento da Inspeção Industrial e Sanitária de Produtos de Origem Animal RIISPOA. (2001). Pescados e derivados. Brasília. Cap. 7, seção 1.

Bugueño, G.; Escriche, I. and Martinez-Navarrete, N.; Camacho, M. M. and Chiralt, A. (2003). Influence of storage conditions on some physical and chemical properties of smoked salmon (Salmo salar) processed by vacuum impregnation techniques. Food Chemistry, 81, 85-90.

Burt, J. R. (1988) Fish smoking and drying: the effect of smoking and drying on the nutritional properties of fish. London: Elsevier. pp. 41-52.

Cardinal, M.; Knockaert, C.; Torrissen, O.; Sigurgisladottir, S.; Mørkøre, T.; Thomassen, M. and Vallet, J. L. (2001), Relation of smoking parameters to the yield, colour and sensory quality of smoked Atlantic salmon (Salmo salar). Food Research International, 34, 537-550.

Cardinal, M.; Gunnlaugsdottir, H.; Bjoernevik, M.; Torrissen, O. and Knockaert, C. (2004), Sensory characteristics of cold-smoked Atlantic salmon (Salmo salar) from European market and relationships with chemical, physical and microbiological measurements. Food Research International, 37, 181-193.

Costa, A. P. R.; Carneiro, M. J. M.; Cordeiro, C. A. M.; Andrade, D. R. and Souza, G. A. P. (2001) In: Food Science Latin American Symposium, 4., Campinas. Anais... Campinas. pp. 145.

Espe, M.; Nortvedt, R.; Lie, O., and Hafsteinsson, H. (2001), Atlantic salmon (Salmo salar) as raw material for the smoking industry: I. Effect of different salting methods on the oxidation of lipids. Food Chemistry, 75, 411-416. 
Ferreira, S. O. (1987), Aplicação de tecnologia a espécies de pescado de água doce visando atender a agroindústria rural. Master of Science Dissertation. Universidade de São Paulo, Escola Superior de Agricultura "Luiz de Queiroz" - ESALQ-USP, São Paulo, Brazil. 122 pp.

Franco, G. (1992), Tabela de composição química dos alimentos. 9. ed. São Paulo: Atheneu. 89 pp.

González-Fandos, E.; Garía-Linares, M. C.; VillarinoRodríguez, A.; Garcia-Arias, M. T. and GarciaFernandez, M. C. (2004), Evaluation of the microbiological safety and sensory quality of rainbow trout (Oncorhynchus mykiss) processed by the sous vide method. Food Microbiology, 21, 193-201.

Huang, Y.; Cavinato, A. G.; Mayes, D. M.; Bledsoe, G. E. and Rasco, B. A. (2002), Nondestructive predication of moisture and sodium chloride in cold smoked Atlantic salmon (Salmo salar). Journal of Food Science, 67, 2543-2547.

Hultmann, I.; Røra, A. B. M.; Steinsland, I.; Skara, T and Rustad, T. (2004), Proteolytic activity and properties of proteins in smoked salmon (Salmo salar) - effects of smoking temperature. Food Chemistry, 85, 377-387.

Hunt, R. W. G. (1977), The specification of colour appearance - Concepts and terms. Colour Research Applied, 2, 55-68.

Leroi, F.; Joffraud, J. J.; Chevalier, F. and Cardinal, M. (1998), Study of the microbial ecology of coldsmoked salmon during storage at $8^{\circ} \mathrm{C}$. International Journal of Food Microbiology, 39, 111-121.

Mørkøre, T.; Vallet, J. L.; Cardinal, M.; GomezGuillen, M. C.; Montero, R.; Torrissen, O. J.; Nortvedt, R.; Sigurgisladottir, S. and Thomassen, M. S. (2001) Fat content and fillet shape of Atlantic salmon: relevance for processing yield and quality of raw and smoked products. Journal of Food Science, 66, 1348-1354.

Nunes, M. L. (1999), Tecnologia do Pescado: Defumação. In: Ogawa, M. and Maia, E. L. Manual de pesca: ciência e tecnologia do pescado. São Paulo: Elsevier. v. 1. pp. 300-306.

Oetterer, M. (1994), Defumação do pescado em unidades de baixo investimento. In: Fishes Salting and Smoking Technology Symposium Workshop. Campinas: ITAL/CTC. pp. 29-33.

Oetterer, M. (1999), Agroindústria beneficiadoras de pescado cultivado: unidades modulares e polivalentes para implantação, com enfoque nos pontos críticos higiênicos e nutricionais. Thesis (Livre Docência), Universidade de São Paulo, Escola Superior de Agricultura "Luiz de Queiroz", Piracicaba. 196 pp.

Poste, L. M.; Mackie, D. A. and Butler, G. (1991), Laboratory methods for sensory analysis of food. Ottawa: Research Branch Agriculture Canada Publication. 90 pp.
Rasmussen, R. S.; Rønsholdt, B.; Ostenfeld, T. H. and McLean, E. (2001), Growth, feed utilisation, carcass composition and sensory characteristics of raibow trout treated with recombinant bovine placental lactogen and growth hormone. Aquaculture, 195, 367-384.

Røra, A. B. M.; Kvále, A.; Mørkøre, T.; Rørvik, K. A.; Steien, S. H. and Thomassen, M. S. (1998), Process yield, colour and sensory quality of smoked Atlantic salmon (Salmo salar) in relation to raw material characteristics. Food Research International, 31, 601-609.

Røra, A. M. B.; Furuhaug, R.; Fjæra, S. O. and Skjervold, P. O. (2003), Salt diffusion in pre-rigor filleted Atlantic salmon. Aquaculture [in press].

Sanches, L. (1989), Pescado, matéria-prima $e$ processamento. Campinas: Fundação Cargil. 61 pp.

Sheehan, E. M.; O'Connor, T. P.; Sheehy, P. J. A; Buckley, D. J. and FitzGerald, R. (1998), Stability of astaxanthin and canthaxanthin in raw and smoked Atlantic salmon (Salmo salar) during frozen storage. Food Chemistry, 63, 313-317.

Sigurgisladottir, S.; Sigurdardottir, M. S.; Ingvarsdottir, H.; Torrissen, O. J. and Hafsteinsson, H. et al. (2001), Microstructure and texture of fresh and smoked Atlantic salmon, Salmo salar L., fillets from fish reared and slaughtered under different conditions. Aquaculture Research, 32, 1-10.

Sylvia, G.; Morrisey, M. T.; Graham, T. and Garcia, S. (1995), Organoleptic qualities of farmed and wild salmon. Journal of Aquatic Food Production and Technology, 4, 51-64.

Zonta, E. P.; Machado, A. M. and Silveira Jr., P. (1986), SANEST: Sistema de análise estatística para microcomputadores. Pelotas: Universitária. 92 pp.

Received: June 16, 2004; Revised: March 02, 2005; Accepted: August 02, 2005. 